\title{
PODERES DEL JUEZ CIVIL: ALGUNAS CONSIDERACIONES A PROPÓSITO DEL JUEZ DE FAMILIA
}

\author{
Iván Hunter Ampuero*
}

\begin{abstract}
RESUMEN
El autor aborda el problema de la dotación de potestades oficiosas del juez civil-materiales y procesales- desde la actual normativa de los Tribunales de Familia. Para ello, junto con exponer el problema presentado por un sector de la doctrina de la supuesta pérdida de imparcialidad del juzgador cuando aporta prueba al proceso señala cuáles serían los fundamentos de estas potestades en el escenario familiar. Para este efecto realiza un examen dogmático de las potestades materiales del juez de familia, para luego proponer una interpretación de las normas legales conforme a determinadas garantias que aseguran la concurrencia de un juez imparcial como parte del derecho fundamental al debido proceso.
\end{abstract}

JUEZ DE FAMILIA - PODERES DEL JUEZ CIVIL - POTESTADES PROBATORIAS

Powers of the civil judge: some considerations regarding the family judge

ABstract

The author undertakes the problem of giving ex-officio powers, both substantive and procedural, to the family judge, in the light of the current Family Courts legislation. As well as presenting the predicament scholars have put forward regarding the alleged lost of impartiality of the judge in those cases when it is himself who puts forward evidence, the author indicates which are the bases for such powers in a family law context. In doing so, the author makes a dogmatic exam of the substantive powers of the family judge, and later propounds an interpretation of the legal norms according to certain guarantees ensuring the presence of an impartial judge as part of the fundamental right to a due process.

FAMILY JUDGE - POWERS OF THE CIVIL JUDGE - EVIDENTIARY POWERS

* Abogado. Licenciado en Ciencias Jurídicas y Sociales, Profesor de Derecho Procesal y Profesor colaborador de Derecho Civil, Universidad Austral de Chile, Valdivia, Chile, email ihunter@surnet.cl. Artículo recibido el 30 de marzo de 2007 y aceptado para su publicación por el Comité Editorial el 4 de mayo de 2007. 


\section{INTRODUCCIÓN}

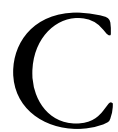

on la dictación de la Ley 19.968 (en adelante la Ley) se crean en nuestro país los Tribunales de Familia. La naturaleza del contencioso familiar y la diversidad de órganos jurisdiccionales encargados del tratamiento de los conflictos familiares reclamaban hace un par de décadas una adaptación de la estructura orgánica y procedimental de nuestros tribunales a los nuevos requerimientos que demandaba la especialización. Sin embargo, junto a este trascendental cambio convergen una serie de cuestiones ideológicas y de pura técnica jurídica que han sido en buena parte ignoradas por el foro.

La doctrina procesal nacional ha terciado en algunos tópicos ligados al ámbito del proceso civil patrimonial, dejando en el olvido la nueva configuración que el ordenamiento ha otorgado al proceso de familia, ${ }^{1}$ la que se ha convertido en una especie de coto inmune a la reflexión teórica y académica. Con todo, los inescindibles puntos de contacto entre el proceso civil patrimonial y el de familia no pueden dejar de llamar la atención a la hora de evaluar su correlatividad con los derechos fundamentales de los justiciables, y constituyen un notable escenario para discutir, con enormes consecuencias en el plano del ser, los problemas a la idea de debido proceso que conllevan las potestades oficiosas de los Tribunales, especialmente en materia de iniciativa probatoria.

Sin que se pretenda cerrar un debate aun abierto en la literatura comparada, estas líneas tienen el deliberado propósito de poner de relieve el rol del juez en materia de familia, con especial atención al respeto del principio dispositivo y de aportación de prueba de parte como integrante del derecho fundamental a un debido proceso. Para esta finalidad se propone no solo un examen de lege lata que se agote en el simple muestreo del estado de la cuestión, sino que además se busca observar una postura que exponga la coherencia -o la falta de ella- entre el derecho procesal de familia y los elementos que buscan conformar el debido proceso como derecho fundamental del justiciable.

En este aspecto no puedo sino efectuar un trabajo integrador de los principios del procedimiento en relación a la actividad probatoria del juez, específicamente en la complementariedad con los principios de bilateralidad, inmediación y la publicidad. Con este propósito he querido comenzar con un análisis doctrinal acerca del problema de las potestades materiales del juez civil a fin de explorar sus aristas más relevantes para la indagación posterior, asumiendo como válida aquella tesis que sustenta la constitucionalidad del juez aportador de prueba. Se trata, primeramente, de una cuestión meramente descriptiva sobre el estado de la discusión en la doctrina científica, con miras a trasladar sus posibles consecuencias al plano normativo nacional, siempre centrado -como se ha explicado- en el ámbito del proceso de familia. Este paso supone además tomar cierta posición sobre el derecho al juez imparcial y verificar su conexión con el derecho fundamental al debido proceso. Luego, en este mismo afán, abordaré con pre-

${ }^{1}$ Hago presente desde ya que el proceso de familia debemos situarlo dentro del rótulo "proceso civil", ya que esta expresión debe entenderse en oposición al proceso penal, por lo mismo, es comprensivo de todo proceso donde se tratan materias no ligadas al ejercicio del ius puniendi estatal. El proceso de familia, laboral o administrativo forman parte, entonces, del proceso civil. 
tensiones descriptivas -y por ende, susceptible de juicio veritativo- el actual diseño procesal en materia de iniciativa probatoria y manejo del iter procesal, para finalizar, ya con pretensiones de corrección, con mi postura sobre la dotación de potestades oficiosas al juez de familia y las garantías que debe revestir dicha actividad.

\section{Poderes del Juez Civil: STAtus questionis EN LA DOCTRINA CIENTÍFICA}

Hace un par de décadas no constituía un problema digno de la doctrina procesal referirse a las consecuencias para la imparcialidad del juez el dotarlo de potestades de manejo del iter procesal. Los jueces dentro de la esfera de sus atribuciones institucionalmente configuradas podían manejar los tiempos dentro del proceso, y la generalidad de las normas procesales observaban tal posibilidad miradas a la finalización temprana de los juicios. La idea del conflicto interminable, lento y de pesado proceder no favorecía a la idea de encontrar la paz social que el proceso estaba llamado a producir como mecanismo institucionalmente ordenado para la resolución de los problemas de la gente. Así resultaba lógico e inevitable que el juez pueda actuar de oficio. La normativa nacional a través del Código de Procedimiento Civil, siguiendo la ordenanza procesal austriaca de Klein de 1895, adoptó dicha idea, configurando una serie de potestades a los jueces tendentes a la temprana y pronta resolución de conflictos.

Sin embargo, los códigos procesales del siglo XX no solo establecieron potestades a los jueces para controlar el iter procesal, sino que también los facultaban para proponer pruebas de oficio en el proceso. Esta dotación de potestades oficiosas al juez y la facultad de éste de aportar prueba al proceso civil han constituido dos temas profundamente discutidos en el foro. A su respecto, la doctrina se encuentra claramente fraccionada, y con exiguos, si no inexistentes, puntos de reunión. Con todo, el problema se muestra como una arista de algo más abstracto y general acerca de la función que cumple la jurisdicción en un Estado de Derecho, y el rol del juez en el proceso civil, por ende, una respuesta a esta interrogante no parte sino de la previa concepción que se sustente sobre aquellas instituciones.

Estas doctrinas, en apretada síntesis, se resumen en dos grandes posiciones. En la primera están aquellos que sustentan la idea de que dotar al juez de facultades para aportar pruebas en el proceso implica despojarlo de su calidad de tercero ajeno a los derechos subjetivos o intereses en litis, cercenando su imparcialidad, creando de paso un mecanismo de prejuzgamiento que, al final de cuentas, termina beneficiando a una de las partes. Esta situación se traduciría en una violación de la garantía del juez imparcial, como parte y contenido del debido proceso.

Así, Montero Aroca ${ }^{2}$ expresa que la posibilidad del juez de proponer pruebas de oficio es incompatible con un proceso acusatorio dado que el sentenciador asumiría

\footnotetext{
${ }^{2}$ Cfr. Montero Aroca, J.: "El proceso civil llamado 'social' como instrumento de 'justicia' autoritaria”, en Proceso Civil e Ideología: un prefacio, una sentencia, dos cartas y quince ensayos, Editorial Tirant Lo Blanch, Valencia, 2006, pp. 157 a 159.
} 
las funciones propias de las partes, con la consecuente pérdida de la garantía de la imparcialidad. Agrega además que cuando se trata de atribuir poderes probatorios al juez lo que debe cuestionarse no es propiamente la imparcialidad judicial, sino que la necesidad de que el juez siga siendo tercero (terzietà), rompiendo la exigencia de incompatibilidad entre parte y juez. En otro lado, el mismo autor distingue entre el aumento de los poderes directivos de los jueces y los poderes materiales. Señala que una cosa es que se produzca un aumento de los poderes procedimentales del juez y otra muy diversa es que ese aumento se refiera a aquellos elementos que puedan servir para determinar el contenido material de la sentencia, como sería el poder acordar medios de prueba de oficio. En el primer caso -señala el autor- se está ante el desarrollo de lo que es el proceso en sí mismo considerado, mientras que en el segundo se está acabando con la imparcialidad del juez. ${ }^{3}$ En otras palabras, se propugna que un juez con poderes probatorios no sería un juez imparcial, rompería con el principio de igualdad de las partes favoreciendo siempre a la demandante y, por lógica, no se respetaría la garantía del derecho imparcial e independiente. ${ }^{4}$

Para esta doctrina además parece ser que un sentenciador con potestades de dirección material, amén de convertirse en juez y parte, atentaría al derecho fundamental a la tutela jurisdiccional efectiva, cuyo contenido presupone que el juez que ha de conocer y satisfacer la pretensión sea imparcial. Como lo afirma González Pérez, la tutela solo será efectiva si el órgano jurisdiccional reúne ciertas condiciones y antes de dictar sentencia sigue un proceso investido de las garantías que hagan posible la defensa de las partes, con la exigencia de un juez imparcial predeterminado por la ley. ${ }^{5}$ En suma, esta doctrina calificando de fascistas y totalitarios ${ }^{6}$ a aquellos sistemas que dotan de facultades materiales a los jueces civiles sustenta serias objeciones constitucionales y

${ }^{3}$ Cfr. Montero Aroca, J.: Los principios políticos de la nueva ley de Enjuiciamiento Civil. Los poderes del juez y la oralidad, Editorial Tirant Lo Blanch, Valencia, 2001, p. 56.

${ }^{4}$ Así lo dice expresamente, por ejemplo, en Chile Botto Oakley, Hugo, a propósito de las medidas para mejor resolver, que según el autor serían inconstitucionales en razón de lesionar la exigencia del procedimiento racional y justo y, por añadidura, la garantía del debido proceso. Botto, H.: Inconstitucionalidad de las Medidas para Mejor Resolver, Editorial Fallos del Mes, 2001, pp. 62 a 64.

${ }^{5}$ Cfr. González Pérez, J.: El Derecho a la Tutela Jurisdiccional, Editorial Civitas, $3^{\text {a }}$ edición, pp. 164 y 165 .

${ }^{6}$ La calificación de fascistas y totalitarios de los sistemas que admiten la iniciativa probatoria del juez en materia civil tiene una génesis eminentemente política. En efecto, Montero Aroca señala que "el aumento de los poderes del juez en materia probatoria no puede dejar de ser un reflejo del aumento de los poderes del Estado en la sociedad, aumento que responde a una concepción autoritaria del propio Estado y, por consiguiente, del papel del juez en el proceso civil”. Montero Aroca, J.: "El proceso civil llamado 'social' como instrumento de 'justicia' autoritaria”, op. cit., p. 153. Del mismo autor puede verse además "Sobre el mito autoritario de la 'buena fe procesal'”, en Proceso Civil e Ideología: un prefacio, una sentencia, dos cartas y quince ensayos, op. cit., pp. 329 y 330. Para esta doctrina detrás del pretendido criterio técnico de las potestades materiales del juez civil se esconden fuertes razones políticas e ideológicas ligadas al fortalecimiento de la autoridad estatal en la esfera privada, propio de los Estados totalitarios y fascistas. Puede consultarse además: Cipriani, F.: Ideologia e modelli del processo civile, Edizioni Scientifiche Italiane, Nápoles, 1997, passim. Del mismo autor: "El proceso civil entre viejas ideologías y nuevos eslóganes", en Proceso Civil e Ideología: un prefacio, una sentencia, dos cartas y quince ensayos, op. cit., p. 82 a 95, también publicado en Rivista di Diritto Processuale, 2003, N 2 2, pp. 445 a 466. Monteleone, G.: "Principios e ideologías del proceso civil. Impresiones de un 
graves atentados al debido proceso, por la pérdida de la imparcialidad y la calidad de tercero del juez.

En Chile, Palomo ha sostenido que "las posiciones adscritas o inspiradas en el señalado fenómeno de la socialización del proceso civil pecan, con buenas intenciones, de irrealismo utópico (sic). Lo que se persigue con la prueba no es otra cosa que la convicción psicológica del juez respecto de la verdad o certeza de los hechos afirmados por las partes. La finalidad de la prueba civil no radica (porque no puede) en la verdad histórica o en la realidad material de los hechos, sino en la obtención de la convicción subjetiva que el juzgador logre formarse una vez practicadas las pruebas". ${ }^{7}$ Agrega con posterioridad que "pretender articular el diseño procesal de un 'super juez civil', por sobre todas las cosas activista y poseedor de considerables y amplias facultades en materia de iniciativa probatoria, es sin dudas ilusorio, pero también puede resultar atentatorio al deber de imparcialidad judicial en aquellos casos en que se utilicen efectivamente". 8

Para otro sector de la doctrina, sustentada en la literatura comparada por Picó i Junoy y en Chile principalmente por Bordalí, la objeción constitucional al juez con poderes materiales ha sido exagerada y erróneamente entendido en la doctrina. Picó i Junoy entiende que "al juez se le puede atribuir iniciativa probatoria siempre que se limite a los hechos discutidos en el proceso -por lo que se protege el principio dispositivo-, a las fuentes probatorias que ya consten en la causa-impidiendo así una actuación inquisitoria, susceptible de vulnerar la debida imparcialidad judicial-, y que permita el ejercer el derecho a la defensa a los litigantes, ampliando sus pruebas inicialmente propuestas". ${ }^{9}$ Bordalí, ${ }^{10}$ por su parte, contrariando a los "revisionistas" 11 aborda su tesis conforme a los elementos reseñados anteriormente; el rol del juez civil y la función de la jurisdicción. En efecto, el autor señala que en relación a la posición del juez en un proceso civil respetuoso de los derechos e intereses de los ciudadanos, se debe arrancar necesariamente de los principios de oportunidad y dispositivo. ${ }^{12}$ Estos se manifiestan

'revisionista'”, en Proceso Civil e Ideología: un prefacio, una sentencia, dos cartas y quince ensayos, op. cit., p. 97 a 107, también publicado en Rivista Trimestrale di Diritto e Procedura Civile, 2003, pp. 575-582.

${ }^{7}$ Palomo, D.: "Proceso Civil Oral: ¿Qué modelo de juez requiere?”, en Revista de Derecho Universidad Austral de Chile, Vol. XVIII, No 1, julio, 2005, p. 186, y también del mismo autor "Sobre el papel del juez civil en materia de prueba, especialmente de las medidas para mejor resolver. A propósito de la paradoja que evidencia nuestro sistema procesal tras la Reforma procesal penal”, en Revista Gaceta Jurídica, $\mathrm{N}^{\circ} 3$, junio, 2005, pp. 7 a 18.

${ }^{8}$ Palomo, D.: “Proceso Civil Oral: ¿Qué modelo de juez requiere?”, op. cit., p. 186.

${ }^{9}$ Cfr. Picó i Junoy, J.: "El derecho procesal entre el garantismo y la eficacia: Un debate mal planteado", en Proceso Civil e Ideología, Montero Aroca, J. (coord.), Editorial Tirant Lo Blanch, p. 120.

${ }^{10}$ Cfr. Bordalí, A.: "Los Poderes del Juez Civil", en Pensando en una nueva Justicia Civil, Editorial Jurídica de Chile (en prensa), pp. 10 y ss.

${ }^{11}$ El término "revisionista" ha sido acuñado por la doctrina a propósito del mea culpa efectuado por un grupo de procesalistas autodenominados "garantistas”, que en su época abrazaron la tesis de la publicización del proceso civil, y por ende, asumieron como válidas las potestades oficiosas de juez en materia civil. Ahora no solo repudian dichas ideas, sino que además las califican de fascistas y totalitarias.

${ }^{12}$ Cfr. Bordalí, A.: "El debido proceso civil", en La Constitucionalización del Derecho Chileno, Universidad Austral de Chile, Editorial Jurídica de Chile, 2003, p. 268. 
básicamente en que la aportación del material fáctico referido a la pretensión y la resistencia es privativa de las partes, que delimitarán el objeto de la controversia, sin que exista una facultad indagatoria por parte del juez. De igual forma, el principio dispositivo dirá que las partes son libres para disponer de los derechos e intereses en conflicto, poniendo término al proceso cuando lo estimen conveniente. Según Bordalí, aquí se agota el contenido del principio dispositivo, por lo mismo, la aportación de pruebas queda fuera del mismo: se trataría de una cuestión de pura técnica jurídica alejada, por tanto, de valoraciones ideológicas. En el mismo sentido Picó i Junoy entiende que la aportación de prueba de parte es un expediente eminentemente técnico que corresponde a un particular modo de concebir el desarrollo del proceso jurisdiccional. ${ }^{13}$ Arrancando del respeto irrestricto de las partes para aportar prueba al juicio, el legislador podría atribuir poderes probatorios al juez, o no hacerlo, y ambas se ajustan a las exigencias constitucionales, como se justificará más adelante.

Aun cuando sustentar la plena vigencia del principio dispositivo podría exigir afirmar que todo el material probatorio deba ser introducido a iniciativa de parte con objeto de mostrar la verdad o falsedad de los enunciados fácticos que determinan el presupuesto de la pretensión y resistencia, la realidad de las reglas procesales, incluso aquellas respaldadas en códigos de regímenes liberales y, por ende, sólidamente adheridas a dicho principio, consienten, en mayor o menor grado, que el material probatorio incorporado al proceso por los litigantes sea complementado o integrado por propia iniciativa del órgano judicial.

Frente a esta realidad el problema de las potestades probatorias del juez debe dejar de ser el centro gravitacional de la discusión teórica para trasladarse hacia los límites de dicha potestad y los presupuestos de su aplicación, ${ }^{14}$ los que no parecen haber sido abordados por aquellos que rechazan esta idea. Si al menos resulta claro que ninguna legislación ha hecho abandono total de la facultad probatoria del tribunal y que no se han presentado objeciones prácticas a la noción de imparcialidad del juzgador, parece razonable destinar los mejores esfuerzos a mejorar la actual configuración normativa o al menos a interpretar las actuales normas conforme al debido proceso.

\section{3. ¿Y QUÉ DiCE NUESTRA LEY ACERCA DE LAS POTESTADES DEL JUEZ DE FAMILIA?}

La ley de tribunales de familia contempla un crisol no despreciable de potestades oficiosas, tanto formales como materiales. Al respecto podemos distinguir con suma

${ }^{13}$ Cfr. Picó i Junoy, J.: "El derecho procesal entre el garantismo y la eficacia: Un debate mal planteado", op. cit., p. 122. Del mismo autor: "Los principios del Nuevo Proceso Civil Español”, en XVII Jornadas Iberoamericanas, XI Jornadas Uruguayas de Derecho Procesal, en Homenaje a la Escuela Procesalista Uruguaya, 16 al 18 de octubre de 2002, Fundación de Cultura Universitaria, Montevideo, p. 189.

${ }^{14}$ Vid., en el mismo sentido, Picó i Junoy, J.: "La iniciativa probatoria del juzgador penal y la imparcialidad judicial”, en XVII Jornadas Iberoamericanas, XI Jornadas Uruguayas de Derecho Procesal, en Homenaje a la Escuela Procesalista Uruguaya, op. cit., p. 383. 
nitidez entre aquellas potestades ligadas al manejo del iter procesal, meramente formales, que se agotan en la simple posibilidad de que el juez pueda tener el dominio absoluto de los tiempos procesales, con independencia a la actividad que efectúen las partes. En el otro lado, encontramos las potestades materiales o de fondo, donde el juez puede ingresar prueba no contemplada por las partes, excluir otras tantas, y aun pasar por encima de la prueba rendida por ellas; esta arista constituye el problema planteado y puede constituirse en un buen aliciente a una indagación conforme al debido proceso.

Ahora bien, no obstante reconocer que la separación entre potestades procesales y materiales es la summa divisio se pueden observar ciertas facultades que no encuadran en forma pura dentro de las potestades formales o materiales; me refiero a la potestad cautelar general del Art. 22 de la Ley y a ciertas facultades de promover la mediación y la conciliación (Art. $61 \mathrm{~N}^{\text {os. }} 4$ y 5), que están destinadas a resguardar el peligro que una sentencia tardía puede significar para los justiciables o a poner pronto remedio al conflicto mediante soluciones autodeterminadas. Las primeras no están miradas a poner pronto término al pleito, todo lo contrario, su operatividad supone implícita la necesaria tardanza que significa desarrollar un debido proceso. ${ }^{15}$ Tampoco suponen, al menos conceptualmente, una decisión del fondo del asunto, es decir, no pueden calificarse sin cortapisa de materiales. Las segundas, en cambio, imprimen el indispensable aire colaborativo que debe reinar en el conflicto de familia, amén del tratamiento que merece una problemática que excede con creces a la mera definición de derechos, cercana, por cierto, a criterios de equidad. Si entendemos de esta forma a la mediación y conciliación tampoco entonces podemos ligarlas a una potestad material.

Veamos algunas de las disposiciones que constituyen un buen estandarte de estas potestades.

\subsection{Potestades ligadas al iter procesal}

La primera norma relacionada al manejo del tiempo procesal la encontramos a nivel de los principios del procedimiento, donde se consagra la actuación de oficio del Tribunal. En efecto, el Art. 13 dispone que "promovido el proceso y en cualquier estado del mismo, el juez deberá adoptar, de oficio, todas las medidas necesarias para llevarlo a término con la mayor celeridad". Se trata de una facultad ligada claramente a los tiempos procesales, donde se recoge la idea de la temprana resolución del conflicto. Su instauración expresada a nivel de principio constituye una novedad en nuestro proceso

${ }^{15}$ Siguiendo a Ortells, cabe considerar que la realización de los actos propios del proceso -contradicción entre las partes y prueba de las alegaciones, entre otros- requiere para su materialización de un espacio relevante de tiempo, de manera tal que el órgano jurisdiccional pueda alcanzar el material indispensable para la dictación de una sentencia acertada y justa. "Aquella demora supone la posibilidad, la ocasión, de que el demandado realice actos que impidan o dificulten la efectividad de la satisfacción que la sentencia venga, al final de cuentas, en conceder al actor". La tutela cautelar, de dicha forma, se constituye en un instrumento jurídico que posibilita la realización del proceso, es la medida de contrapeso a la necesaria tardanza que supone desarrollar un debido proceso. Ortells, M.: Las Medidas Cautelares, $1^{a}$ edición, Editorial La Ley, Madrid, 2000, pp. 35 a 37. En el mismo sentido, Marín, J.C.: Las Medidas Cautelares en el Proceso Civil Chileno. Doctrina, jurisprudencia y derecho comparado, Editorial Jurídica de Chile, Santiago, 2004, p. 232. 
civil, ya que además de ciertas normas aisladas no existía una norma que repartiera el impulso procesal entre las partes y el juez en forma indistinta, en la forma que viene consagrado en la normativa de familia. Esto ha hecho que alguna doctrina señale que en el proceso de familia coexistan los principios dispositivo e inquisitivo, con preponderancia de este último atendida la naturaleza del conflicto familiar. ${ }^{16}$ Especial énfasis debe colocarse en este aspecto de la celeridad procedimental cuando existen menores dentro de la reyerta familiar, amén de la obligación que ha asumido nuestro Estado en virtud de la Convención sobre Derechos del Niño de dirimir sin demora las causas donde estén involucrados menores. ${ }^{17}$ Por lo mismo, una interpretación coherente sería sustentar que el juez ha de jugar un rol más activo en la dirección y dominio de los tiempos procesales del conflicto, mientras más grave sea el estado de insatisfacción de los derechos e intereses de los niños, niñas o adolescentes.

\subsection{Potestades materiales o ligadas al fondo del asunto}

Aun a riesgo de caer en un puro y simple examen dogmático, que no constituye el objeto exclusivo de este trabajo, se debe señalar que existen dos clases de potestades materiales ligadas al fondo del proceso familiar. ${ }^{18}$ Las primeras, que denominaremos indirectas, se encuentran consagradas en el Art. 29 inciso $1^{\circ}$ de la Ley que señala: "Las partes podrán, en consecuencia, ofrecer todos los medios de prueba de que dispongan, pudiendo solicitar al juez de familia que ordene, además, la generación de otros de que tengan conocimiento y que no dependan de ellas, sino de un órgano o servicio público o de terceras personas, tales como pericias, documentos, certificaciones u otros medios aptos para producir fe sobre un hecho determinado". La aportación de estas pruebas nace a petición de la parte interesada, es decir, respeta completamente el principio de aportación de prueba de parte, sin que, al menos formalmente, merezcan un reproche desde el punto de vista de la imparcialidad del juzgador. Con todo, la razón por la cual he decidido incluirlas dentro de rótulo obedece que, al final de cuentas, es resorte del juez acceder o no a estas pruebas conforme la facultad del Art. 31 de la misma Ley, ${ }^{19}$

${ }^{16}$ Vid. Jara, E.: "Los procedimientos de la Ley 19.968, a la luz de los principios", en Derecho de Familia e Infancia, Seminario Internacional, Academia Judicial de Chile, 2005, p. 114.

${ }^{17}$ El Art. $40 \mathrm{~N}^{\circ} 2$ letra iii) de la Convención sobre Derechos del Niño obliga al Estado a asegurar respecto del niño "Que la causa será dirimida sin demora por una autoridad u órgano judicial competente, independiente e imparcial en una audiencia equitativa conforme a la ley..."

${ }^{18}$ Como bien lo observa Cortez, el proyecto de ley original -y que fuera objeto de comentario por el autor- no planteaba en principio la posibilidad de que el juez de familia aportara prueba al proceso, contemplando el proyecto solo la posibilidad de que sean las partes las que exclusivamente aporten prueba al proceso. Con todo, el autor propone con suma lucidez la posibilidad de ingresar esta potestad oficiosa con las limitaciones derivadas de la exigencia del juez imparcial y el respeto a los principios dispositivo y de contradicción. Vid. Cortez, G.: "Breves comentarios sobre los principios del procedimiento, la prueba y la cautela en el proyecto de ley que crea los Tribunales de Familia”, en Revista de Derecho de la Universidad de Concepción, No 209, año 2001, p. 103.

${ }^{19}$ El juez de familia en la audiencia preparatoria puede ordenar la exclusión de las pruebas que fueren manifiestamente impertinentes, tuvieren por objeto acreditar hechos públicos y notorios, resulten 
por lo mismo, sigue siendo una prueba cuya introducción al mérito depende de uso de una potestad material.

En segundo término encontramos las potestades materiales directas contenidas en el Art. 29 inciso $2^{\circ}$ de la Ley, donde el juez, de oficio, puede ordenar que se acompañen todos aquellos medios de prueba de que tome conocimiento o que, a su juicio, resulte necesario producir en atención al conflicto familiar de que se trate. Misma fórmula se repite en el Art. 45 inciso final de la Ley cuando faculta al juez para que de oficio solicite la elaboración de un informe de peritos a algún órgano público u organismo acreditado ante el Servicio Nacional de Menores que reciba aportes del Estado, cuando lo estime indispensable para la adecuada resolución del conflicto. Se trata, sin lugar a dudas, de una potestad material directa, donde el juez puede aportar prueba al proceso sin más limitación que su necesariedad para la resolución del conflicto de que se trate. Cabe precisar en este aspecto que he deliberadamente excluido de esta potestad material oficiosa la posibilidad del juez de interrogar a los testigos y peritos, por estar ligada más a la rendición de la prueba misma que a su aportación en el proceso, lo que no obsta que puedan formularse reparos en el mismo sentido que analizaré.

\section{Fundamento de las potestades oficiosas}

Aun cuando deba asumirse el carácter técnico de las potestades oficiosas del juez de familia, su fundamentando último escapa a mi juicio al solo derecho procesal, en la medida que obedecen a cierta configuración previa proveniente del derecho sustantivo.

En este sentido, se puede afirmar desde ya que estas facultades oficiosas se observan en un alto grado de coherencia con el rol que le viene asignado desde el derecho material de familia. En efecto, el juez de familia, por ejemplo, es el encargado de definir en el caso concreto cuál es el interés superior del menor para efectos de suspender el ejercicio de la relación directa y regular entre un padre o madre y el hijo (Art. 229 inciso $2^{\circ}$ del Código Civil); debe determinar el interés del menor para efectos de entregar el cuidado personal de menor al otro de los padres (Art. 225 inciso $3^{\circ}$ del Código Civil); debe proteger al cónyuge más débil, previa determinación de cuál de las partes es la más débil (Art. 3 de la Ley de Matrimonio Civil); debe definir si el acuerdo presentado por los cónyuges al poner término a su matrimonio es completo y suficiente, sopesando la suficiencia en términos del resguardo al interés superior del menor, etc.

Al respecto, se puede decir que la actual normativa material de familia confía -incluso en demasía- en el criterio del juzgador para la concretización de indudables conceptos indefinidos, es decir, el juez tiene como función formalizar una tarea de completación de la terminología legal incompleta. ${ }^{20}$ En similar sentido Berizonce señala "que en el

sobreabundantes o hayan sido obtenidas con infracción de garantías fundamentales, o también denominada exclusión de prueba ilícita.

${ }^{20}$ Esta idea de juez completador de los términos legales puede en ciertos casos restarle imparcialidad en la medida que pueda verter en su decisión su propia concepción acerca del derecho y ponga sobre la mesa 
conflicto familiar converge directamente el orden público general, en particular cuando incide en la posición del menor o incapaz. El legislador tipifica el presupuesto de hecho de la norma en el cual la tutela del interés deviene necesaria, mas es el juez quien le da impulso y lo concretiza al caso específico. De esto se deriva que, en el proceso que nos ocupa, vengan atribuidos al órgano jurisdiccional poderes excepcionales, no solo para el control e instrucción de la causa, sino también en orden al contenido propio de la decisión y a la efectiva ejecución. El juez de familia de yergue como el guardián y ejecutor del orden público familiar". ${ }^{21}$ Por ello resulta coherente que a un juez con facultades de completitud de normas y tutelador de los intereses que subyacen en el orden público familiar, le sea asignado, en el mecanismo donde efectúa dicha tarea -el proceso-, un papel protagónico al momento de enfrentar el conflicto y buscar su solución. La articulación del modelo formal para el tratamiento de la controversia de familia supone la exaltación de la figura del juez.

Cabe anotar en esta materia lo sustentado por Meneses Pacheco quien descarta por completo esta idea. Para el autor la procedencia de la iniciativa probatoria del Tribunal no hay que buscarla en el derecho sustantivo, ni menos una explicación política o material, sino más bien en razones de carácter técnico relativas al proceso mismo por tener ésta una connotación meramente procesal. ${ }^{22}$ Creo que la opinión del autor es parcialmente correcta. Si bien la prueba se vincula necesariamente al proceso y es en él donde tiene relevancia, no es posible obviar que el derecho sustantivo determina un especial esquema para el juez en la solución de los conflictos de familia, que debe traducirse necesariamente en un diseño procesal diverso a la mera resolución de un conflicto patrimonial. Por lo mismo, hay un interés en la decisión que sobrepasa por completo la mera técnica jurídica, ya que es el juez el encargado de proteger y tutelar ciertos intereses superiores. Así, por ejemplo, si el juez debe definir qué es el interés superior del niño, lo más lógico es que cuente con facultades para determinar cuál es dicho interés en el caso sub judice, por lo cual, el legislador debe dotarlo de ciertas potestades materiales. La idea del juez como mero espectador o simple instructor del proceso resulta claramente incongruente con la misión que es asignada por la ley sustantiva. No se crea que por esto confundo el interés material ventilado en el proceso con el proceso mismo. La iniciativa del órgano jurisdiccional de familia, a diferencia del civil patrimonial, no solo salvaguarda intereses privados o disponibles, sino que además intereses públicos. En el primer caso, no se desvirtúa la naturaleza de dichos intereses por el hecho de aportar prueba; siguen siendo privados. Y en los segundos -los públicos-, la iniciativa probatoria no es más que una fórmula armónica con dicha función protectora.

sus propios valores. Con todo, el problema no solo se presenta en esta área del derecho, sino que es común con el derecho civil patrimonial que se vale de la utilización de conceptos válvulas para configurar límites a la autonomía privada a través, por ejemplo, de la buena fe, el orden público, la moral o las buenas costumbres, que constituyen verdaderas cláusulas genéricas de encausamiento contractual.

${ }^{21}$ Berizonce, R.: “Tribunali e proccesi di famiglia”, en Rivista Trimestrale di Diritto e Procedura Civile, $\mathrm{N}^{\circ}$ 2, Vol. LVII, 2003, p. 547. La traducción es mía.

${ }^{22}$ Meneses, C.: Iniciativa Probatoria del Juez Civil, Editorial Conosur Ltda., 2001, p. 32. 
Este deber jurisdiccional de protección de los intereses públicos en el proceso familiar proviene tanto de las normas sustantivas como de las procesales, siendo las primeras las que dotan al juez de un amplio poder configurador de la norma jurídica para la adjudicación del caso. He aquí una principal diferencia con aquellos procesos donde existe un interés general comprometido, ya sea el penal o administrativo. En éstos la tutela de dichos intereses no queda entregada al juez sino a otros órganos del Estado, como el Consejo del Defensa del Estado o el Ministerio Público.

En otro giro, la doctrina nacional del derecho de familia ha registrado en la evolución de esta rama un campo de actuación para el juez cada vez más fecundo. Tapia señala que el derecho de familia dejó de tener un carácter didáctico para convertirse en un derecho de carácter terapéutico, y como tal, dejó de definir un camino a seguir, para preocuparse de regular los conflictos de familia cuya solución no fuere encontrada en el seno familiar. ${ }^{23}$ En otras palabras, el derecho de familia sufre un claro repliegue en pos de las libertades individuales para constituir su centro gravitacional en la solución de los problemas de familia. Corral, por su parte, afirma que en la reformulación actual del rol Derecho de Familia este "no debiera ser orientativo, pedagógico o docente, sino más bien terapéutico o compositivo: el establecimiento de procedimientos eficaces para la solución de conflictos y para la armonización hasta donde sea razonablemente posible de los intereses en juego en caso de fractura o ruptura de la convivencia familiar, sería el fin más propio del Derecho de Familia contemporáneo (...) las reglas sustantivas debieran fijarse en función de una posible reyerta. Los tribunales de familia y el diseño de medios alternativos de resolución de conflictos, entre los cuales destacan los mecanismos de mediación familiar, constituirían los centros de preocupación genuina del sistema jurídico de la familia". ${ }^{24}$

Estas ideas, reflejos del actual estado del derecho de familia, no dejan duda que el conflicto de familia compone el actual desvelo del Estado en la materia, y constituye un espacio -quizás el único- donde le es lícito entrometerse para asegurar la adecuada conjugación de los intereses en disputa. En este sentido, resulta manifiesto que si la intervención estatal se ha injertado hacia la esfera del conflicto -y por ende del proceso que constituye la herramienta institucionalmente configurada para su resolución-, se deba necesariamente dotar al poder estatal -representado en el juez-de amplias facultades para adoptar la mejor solución posible, de manera de tutelar el interés general que se encuentra comprometido en el litigio de familia, especialmente cuando existen intereses superiores. El proceso de familia no puede ignorar que de su objeto derivan graves consecuencias en el plano social, económico, jurídico y sobre todo el moral, que inciden fuertemente en toda la comunidad, lo que hace exigible una magistratura altamente activista, de acompañamiento y protección, para la tutela privilegiada de los intereses

${ }^{23}$ Cfr. Tapia, M.: Código Civil 1855-2005. Evolución y Perspectivas, Editorial Jurídica de Chile, 2005, pp. 104 y 105. En similar sentido, Barros, E.: "La ley civil ante las rupturas matrimoniales”, en Estudios Públicos $\mathrm{N}^{\circ} 85,2002$, pp. 5 y ss.

${ }^{24}$ Corral, H.: "Claves para entender el derecho de familia contemporáneo", en Revista Chilena de Derecho, Vol. 29, No 1, 2002, p. 31. 
públicos envueltos. ${ }^{25}$ No se crea que esta función terapéutica ha de desplegarse como una suerte de mediación; el juez de familia debe preocuparse de solucionar el conflicto desde su espacio institucionalmente configurado, con pleno respeto de los derechos de los justiciables y conforme a un debido proceso, tratando de arribar a la solución que el ordenamiento jurídico le permite en el caso concreto.

Así las cosas, una tal concepción de la función del Estado -y por ende del Derecho- en la solución de los conflictos de familia reclama, sin lugar a dudas, que el juez pueda y deba asumir una actividad fundamental en la búsqueda de la verdad a fin de que la sentencia se apegue lo más posible a la realidad fáctica donde el juez está llamado a aplicar el derecho. En el Estado de Derecho, el juez en el ejercicio del monopolio jurisdiccional debe a lo menos intentar acercarse lo más posible a la verdad histórica que debe reconstruir de acuerdo a los hechos alegados por las partes, más aun cuando su decisión definirá la suerte de los derechos e intereses legítimos que configuran un determinado orden público familiar. ${ }^{26}$ La prueba "debe ser considerada como el medio a través del cual el Derecho pretende determinar la verdad de las proposiciones en el marco del proceso judicial", ${ }^{27}$ es decir, la verdad de los enunciados fácticos en cuanto presupuesto normativo de aplicabilidad de las normas constituye el telos que orienta la actividad probatoria.

En este sentido el proceso de familia, más que cualquier otro, requiere, como condición necesaria para la justicia de la decisión, la veracidad de los hechos, es decir, es necesario que el proceso se funde en la mejor aproximación posible a la realidad empírica, aun cuando se trate de una aproximación relativa en función de la extensión y utilidad epistémica de las pruebas disponibles. ${ }^{28}$ Cuando esta aproximación a la realidad, indispensable para la justicia de la decisión, no es develada por las partes a través de sus pruebas, es el juez desde su posición institucional quien debe asumir dicha tarea, efectuando una labor de complementación del material probatorio. "Entra al juego -al menos de manera tendencial- una especie de criterio de plenitud del material probatorio de acuerdo con el cual todas las pruebas relevantes deben ser adquiridas, a iniciativa de parte o, si es necesario, a iniciativa del juez". ${ }^{29}$

${ }^{25}$ Vid. Berizonce, R.: "Tribunali e proccesi di famiglia”, op. cit., p. 560.

${ }^{26}$ Dellepiane hace una analogía entre la función del juez y del historiador. Al respecto, el autor señala: "Sentado que probar un hecho es establecer su existencia, es demostrar que existió antes o que existe en la actualidad, resulta evidente que esta primera tarea del juez se confunde con la del historiador en cierto sentido. La analogía entre la misión del historiador y de la juez, entre la prueba judicial y la histórica, radica, desde luego, en la identidad de fines, dado que la última se propone también establecer hechos pretéritos, mostrar y explicar cómo pasaron las cosas en el pasado”. Dellepiane, A.: Nueva Teoría de la Prueba, Editorial Temis, Bogotá, 2003, p. 14.

${ }^{27}$ Ferrer, J.: Prueba y verdad en el Derecho, Editorial Marcial Pons, Madrid, 2002, p. 34.

${ }^{28}$ Vid. Taruffo, M.: "Algunos comentarios sobre la valoración de la prueba”, en Discusiones (Publicaciones periódicas), $\mathrm{N}^{\circ} 3,2003$, pp. 86 y 88, y también del mismo autor, con mayor desarrollo, "Idee per una teoria della decisione giusta”, en Sui Confini, Scritti sulla giustizia civile, Bolonia, 2002, pp. 224 y 225.

29 Taruffo, M.: “Algunos comentarios sobre la valoración de la prueba”, op. cit., p. 96. 
Si admitimos esto como elemento esencial de la función jurisdiccional entonces nos encontraremos con un sistema que produce decisiones más “justas”, que respetan plenamente los derechos subjetivos o intereses legítimos de los justiciables y que permiten la tutela de aquellos intereses familiares que el Estado debe necesariamente proteger. En consonancia con lo expuesto, Verde señala que "es obvio que dentro del proceso, el poder de intervención del juez será tanto mayor cuando más contenido tenga el objetivo de 'justicia' que se intenta conseguir, y es posible que, por tal vía, se reconozcan al juez facultades que incidan en el sector de la 'tutela', que debería circunscribirse al monopolio exclusivo de las partes, o que de algún modo interfieren en dicho sector". 30

Debe agregarse que la prueba aportada por el juez, lejos de buscar el beneficio de una de las partes, tiene un desinterés objetivo, no está destinada a convencerse sobre la factibilidad de la pretensión o resistencia -aunque ciertamente desencadene, por el principio de inexcusabilidad, a pronunciarse en uno u otro sentido-, sino que alcanzar, dentro de los estrictos términos en que las partes situaron el objeto de litigio, aquella verdad extraprocesal, a fin de importarla y convertirla en una verdad endoprocesal. La prueba, en virtud de la adquisición procesal, al margen de quien la rinda, pertenece siempre al proceso, por lo mismo, el juez que aporta prueba no lo hace para beneficiar a alguna de las partes. ${ }^{31}$ De ser ello así, se podrán reconstruir aquellos hechos históricos que sirven al juez de presupuesto de aplicación de los mandatos generales y abstractos contenidos en las normas jurídicas, reconstruyendo la legalidad y realizando los derechos que el ordenamiento jurídico ha reconocido a los ciudadanos. ${ }^{32}$

Es por ello que aquella idea que niega la potestad probatoria del juez sobre la base de una cierta función subjetiva o del mero convencimiento íntimo del juez ${ }^{33}$ no resulta del todo correcta, ya que no se trata de un problema que ha de ser resuelto conforme a una determinada concepción de la función de la prueba. No hay un correlato necesario entre la interdicción de potestades probatorias del juez y aquella función probatoria ligada al convencimiento moral del juzgador. En ambas concepciones -verdad o convicción- la prueba ex officio jugará roles diferentes: en una, descubrir la verdad o falsedad de las afirmaciones factuales, y en la otra, lograr el convencimiento del juzgador. En este último caso el juez no pierde su imparcialidad dado que desconoce por completo el contenido de la prueba agregada al proceso, por lo mismo, el resultado de la actividad probatoria puede perfectamente terminar convenciéndolo del hecho contrario al que se quiere probar. Solo si se asume ex ante que la prueba ofrecida por el Tribunal terminará logrando su convicción en el caso concreto puede objetarse la garantía de la imparciali-

${ }^{30}$ Verde, G.: "Las ideologías del proceso en un reciente ensayo", en Proceso Civil e Ideología: un prefacio, una sentencia, dos cartas y quince ensayos, op. cit., p. 72, y en su versión italiana: "Le ideologia del processo in un recente saggio", en Rivista di Diritto Processuale, año LVII (seconda serie), Nº 3, 2002, p. 680.

${ }^{31}$ En el mismo sentido, Picó i Junoy, J.: "Los principios del Nuevo Proceso Civil Español”, op. cit., p. 205 .

32 Vid. Bordalí, A.: "El debido proceso civil”, op. cit., 270.

33 Vid. Palomo, D.: “Proceso Civil Oral: ¿Qué modelo de juez requiere?”, op. cit., p. 186. 
dad judicial. Un juez tal que pretende saber antes de rendirse el contenido del material probatorio puede calificarse, ahora sí y sin más, en un "super juez civil”. 34

Como señala un autor, ${ }^{35}$ si el fin último de la prueba es permitir que la dictación de una sentencia que pueda contar con la adhesión de los miembros de la colectividad nacional en cuyo seno actúa el órgano judicial, en cuanto ésta se configura como auténtica legitimadora de la decisión, la actividad probatoria del tribunal se muestra en simpatía con dicho fin, y por ende, asegura, al menos abstractamente, una decisión más legitimada.

Estas potestades, sin embargo, han de desarrollarse bajo la escrita condición de que no medie agravio al debido proceso bajo el cumplimiento de ciertos presupuestos, los que intentaré desarrollar en el acápite siguiente.

\section{Presupuestos para la aportación de prueba POR PARTE DEL JUEZ DE FAMILIA}

Siguiendo el trazado dispuesto por la doctrina para que el juez pueda decretar medidas probatorias se deben cumplir ciertas garantías mínimas, que vienen exigidas por la idea del derecho fundamental al debido proceso y la garantía del juez imparcial, que implican la concesión a las partes de ciertos "contrapoderes probatorios", de manera de lograr un control al ejercicio del poder probatorio del juez. Estas garantías son las siguientes: a) Controvertir la pertinencia o relevancia de la prueba que se intenta introducir; b) Participar en su realización; c) Producir contraprueba; d) Discutir acerca de la eficacia de la prueba de oficio antes de la decisión. ${ }^{36}$ Picó i Junoy agrega que al juez se le puede atribuir iniciativa probatoria siempre que: e) se limite a los hechos discutidos en el pleito; f) a las fuentes probatorias que ya constan en la causa, y g) se permita ejercer el derecho de defensa a los litigantes, ampliando sus pruebas inicialmente propuestas. ${ }^{37,} 38$

\footnotetext{
${ }^{34}$ Se añaden a lo anterior los problemas que trae para la fundamentación probatoria de la sentencia una noción subjetivista de la prueba. Accatino señala con suma lucidez que "la noción subjetivista de prueba, que vincula los enunciados declarativos de hechos probados con la convicción o la creencia del juez en la verdad de su ocurrencia, pone la exigencia de la fundamentación en un callejón sin salida. Eso porque las creencias son algo que nos sucede, algo cuya ocurrencia no depende de nuestra voluntad, y puesto que solo los actos voluntarios admiten justificación, no habría entonces posibilidad de justificar el resultado de la valoración de la prueba realizada por el juez". Accatino, D.: "La Fundamentación de la declaración de los hechos probados en el nuevo proceso penal. Un diagnóstico", en Revista de Derecho Universidad Austral de Chile, Vol. XIX, No 2, diciembre 2006, p. 20.

${ }^{35}$ Vid. Cabañas, J.C.: La valoración de las pruebas y su control en el proceso civil, Editorial Trivium, 1992 , p. 20 .

${ }^{36}$ Vid. Bordalí, A.: "Los Poderes del Juez Civil", op. cit., p. 14, y del mismo autor, "El debido proceso civil", op. cit., 271.

${ }^{37}$ Cfr. Picó i Junoy, J.: "El derecho procesal entre el garantismo y la eficacia: Un debate mal planteado", op. cit., p. 120.

${ }^{38}$ Aclaro al respecto que no obstante la fácil comprensión de los conceptos vertidos por los autores, ninguno de ellos efectúa un examen acerca del contenido esencial de cada concepto a efectos de fijar su
} 
Estas garantías funcionan como límites a la potestad probatoria del Tribunal en razón a la exigencia del debido proceso, y por tal, constituyen un ideal regulativo de lege ferenda y un criterio interpretativo no despreciable de lege lata, ${ }^{39}$ que obliga al operador a extender o restringir el alcance de la norma, de manera de conjugarla armoniosamente con el debido proceso. La actividad probatoria del Tribunal debe ejercerse con pleno respeto a las garantías del justiciable que conforman el debido proceso en este estadio, específicamente con aquellas que aseguran la imparcialidad del juzgador y el derecho a defensa como derechos fundamentales del justiciable. ${ }^{40}$

Sin embargo, a mi juicio, estos presupuestos solo se hacen reales si se desarrollan en el marco del contradictorio. En efecto, el audiatur et altera pars permite que las partes puedan discutir sobre la prueba ofrecida por el Tribunal, a objeto de ejercer un verdadero control sobre su pertinencia, oportunidad y relevancia. El contradictorio es el primer requisito a través del cual se puede satisfacer el cumplimiento de las garantías señaladas: las partes tendrán la posibilidad y oportunidad de discutir la prueba ofrecida por el tribunal. Así las cosas, el contradictorio se erige no solo en una garantía procesal de carácter general, sino que además, y en el campo específico de la utilización de poderes materiales del juez, constituye un presupuesto de actuación del órgano jurisdiccional, previo y necesario para la verificación de las restantes garantías. Si falta éste difícilmente pueden estar presentes las otras. Lo que se pretende a través de la formulación obligatoria del contradictorio es evitar que el interés público que existe de llegar o acercarse a la verdad para solucionar el conflicto pueda comprometer el derecho a defensa de las partes, o el derecho a rendir contraprueba. ${ }^{41}$ Así se mantiene el ideal del desarrollo del proceso en base a una discusión dialéctica.

\section{Potestades materiales del juez de familia y Debido proceso}

Si bien, como lo he señalado, abstractamente consideradas no me muestro contrario a dotar al juez de familia de potestades de oficio, no es menos cierto que la actual

núcleo insoslayable, cuestión que, sin desconocer su importancia, he querido dejarlo de manifiesto cuando se analicen, ya en el plano de la pura dogmática jurídica, los poderes probatorios del juez de familia.

${ }^{39}$ Respecto a esto último nada nuevo se aporta al debate desde que constituye una arista del proceso de constitucionalización del derecho, que exige la interpretación de la normativa infraconstitucional conforme al debido proceso como derecho fundamental del justiciable. Vid., sobre el tema: La Constitucionalización del Derecho Chileno, op. cit., passim.

${ }^{40} \mathrm{Si}$ bien en nuestro texto constitucional no hay un reconocimiento explícito a tal garantía, al menos de la textura abierta de sus normas (Art. 19 No 3 de la Constitución Política de la República) permiten abrigar el derecho al juez imparcial como parte de un proceso e investigación racionales y justas. Vid. En similar sentido pero llevado al ordenamiento español: Jiménez, R.: Imparcialidad Judicial y Derecho al Juez Imparcial, Editorial Aranzadi, Navarra, 2002, pp. 135-140.

${ }^{41}$ Vid. Comoglio, L.: "Garanzie Minime del 'Giusto Processo' Civile Negli Ordenamenti Latinoamericani”, en Rivista di Diritto Dell Integrazione e Unificacione del Diritto in Europa e in America Latina, No 17, 2004, p. 223 . 
normativa no respetaría el umbral mínimo de garantías procesales para decretar dichas pruebas, que rompen, a mi juicio, uno de los elementos fundamentales del principio dispositivo.

Esta conclusión debería obligar al intérprete, en el mayor de los casos, a comprimir el texto legal para efectos de lograr una armonía con el debido proceso, en el sentido de observar una interpretación acerca de lo que se cree correcto -visión positiva- y por añadidura una delimitación acerca de lo que no puede resultar del trabajo hermenéutico -visión negativa-. Esta es la tarea que intentaré emprender en las líneas que siguen.

\subsection{Potestad probatoria limitada a los hechos del pleito: Una interpretación conforme al debido proceso}

Es un principio inconcuso de la dispositividad procesal que los hechos sean aportados exclusiva y excluyentemente por las partes, las que determinan a través de su pretensión y resistencia los límites fácticos de la litis, marcando el entramado de hecho sobre el cual debe dictarse la sentencia. ${ }^{42}$ No hay más hechos que los invocados por las partes y la prueba debe necesariamente recaer sobre ellos. En este sentido, la norma del Art. 29 inciso $2^{\circ}$ de la Ley contempla una fórmula general que faculta al juez a proponer prueba cuando "resulte necesario en atención al conflicto familiar de que se trate", la que no viene limitada a los hechos del pleito introducidos por las partes, sino que a la naturaleza del conflicto que se ventila. En otras palabras, el juez no está limitado en su prueba -como sí estarían las partes amén del Art. 31 de la Ley- a los hechos alegados sino que a la naturaleza del conflicto, fórmula que a la vez de pretender abarcar todo dice nada. Esto lleva a un doble desenlace: primero, que la prueba aportada por el juez de familia no está limitada a la verificación de verdad o falsedad de los hechos alegados por las partes, sino que está remitida y delimitada por el conflicto familiar, que sobrepasa el relato fáctico, y, segundo, que a través de dicha prueba bien pueden introducirse hechos nuevos al proceso, sin posibilidad de que los sujetos procesales, en el mejor de los casos, pueden rendir contraprueba. Ahora bien, puede argumentarse que esta última cuestión no sería inconveniente desde que el juez de familia puede ignorar los hechos nuevos descubiertos en la prueba al no ser invocados por las partes, sin embargo, ello no es óbice a que el conflicto pueda resolverse en base a la convicción del juzgador sobre la base de dichos hechos, aun cuando no se expliciten en la sentencia. ${ }^{43}$

42 Vid. Cappelletti, M.: Giustizia e Società, Edizione di Comunità, Milán, 1972, p. 29. En esta obra el autor explica y demuestra por qué el Código de Procedimiento Civil italiano de 1940, a partir de los elementos que configuran clásicamente al principio dispositivo, respeta por completo la ideología liberal, no obstante, obedecer a una génesis fascista.

43 Resulta difícil pensar por momento alguno que en una disputa judicial sobre el cuidado personal de un menor al juez le sea indiferente descubrir a través de un examen sicológico que uno de los padres tiene una tendencia a la pedofilia. Aun cuando este hecho no haya sido invocado por las partes y sea ajeno al relato fáctico, sin lugar a dudas condicionará la decisión final del asunto. Es más, atendida la "naturaleza del conflicto de familia" una tal prueba de hace indispensable y fundamental. 
Este es el sentido que debe dársele a la función de la prueba en general, en cuanto destinada tan solo a "demostrar la verdad o falsedad de las afirmaciones factuales", 44 escapan de su objeto aquellos hechos que no sean afirmados por las partes, lo que cae fuera del espacio probatorio y no es más que una "anécdota procesal”, siendo irrelevante verificar su correlación a la realidad empírica. Un juez que no respeta tales límites fácticos deja de desarrollar su papel diseñado institucionalmente para convertirse en un investigador. Dicha idea subyace además en la exclusión de la prueba impertinente, es decir, aquella destinada a la acreditación de hechos que no son relevantes para el juez, en atención de no haber sido invocados por ninguna de las dos partes. Si el juez tiene el deber de excluir la prueba impertinente parece meridianamente claro que no puede ofrecer material probatorio en el mismo sentido.

Por lo mismo, una forma de hacer coherente esta disposición con el principio dispositivo es limitando las potestades probatorias del juez de familia tan solo a los hechos alegados por las partes, alcance que debería darse a la fórmula de la "necesariedad del conflicto". Sostener la tesis contraria, aun cuando pueda respetar el texto legal, rompe con el principio dispositivo que gobierna el proceso civil en particular, pudiendo afectar en este mismo sentido al derecho de defensa de las partes, así como el derecho a un juez imparcial.

\subsection{Potestad probatoria solo a falta de material probatorio: Principio de aportación de prueba por defecto}

En otro vértice, la potestad oficiosa material del juez de familia tampoco respeta al menos formalmente la idea de complementariedad, que en mi concepto debe elevarse a la noción de un verdadero principio de aportación por defecto. En efecto, parece razonable que el principio dispositivo y de aportación de prueba de parte puedan admitir que el juez de familia introduzca al proceso determinados medios de prueba, pero dicha potestad solo resulta legítima cuando se hace en defecto o ausencia de prueba, y no, a mi juicio, cuando la prueba es insuficiente. Ello por dos motivos: primero, porque la determinación de la insuficiencia probatoria implica verificar límites cualitativos de cuándo una prueba es suficiente, labor que solo es válida, a mi juicio, en la sentencia definitiva, de lo contrario se estaría adelantando un juicio sobre el mérito. Segundo, porque de acuerdo al entramado procedimental de la Ley, el juez de familia solo puede aportar prueba en la audiencia preparatoria, por lo que se encuentra materialmente imposibilitado de determinar ex ante si la prueba ofrecida por las partes supera el umbral mínimo de suficiencia. Ya en la audiencia de juicio el juez no puede proponer medios de prueba, por mucho que los rendidos hayan resultado insuficientes. ${ }^{45}$ Incluso los autores

${ }^{44}$ Matheus, C.: "Reflexiones en torno a la función y objeto de la prueba", en Revista de Derecho Universidad Austral de Chile, Vol. XIV, 2003, p. 176. La cursiva es mía.

45 Alguna práctica judicial ha entendido que en este caso el juez podría ingresar prueba al proceso a través de la práctica de una medida para mejor resolver, y ello en virtud de la remisión que efectúa el Art. 27 de la Ley a las Normas Comunes a todo Procedimiento contenidas en el Código de Procedimiento Civil. Ello a mi juicio es erróneo y constituye una vuelta atrás en el espacio ganado por este procedimiento. Una 
que muestran una franca simpatía a la actividad probatoria del Tribunal denotan ciertos límites derivados de la actividad primaria y excluyente de las partes. Taruffo señala que "el rol del tribunal no es tomar el lugar de las partes en la producción de la prueba, ni menos impedir que las partes presenten "su" prueba. Si las partes son exitosas en el ofrecimiento de toda la prueba disponible, el tribunal puede no hacer uso en absoluto de sus poderes. Es sólo cuando la actividad de una de las partes, o ambas, no resulta suficiente en la presentación de prueba para establecer la verdad de los hechos que el Tribunal debiera jugar su rol activo". ${ }^{6}$

En este sentido, cabe observar una postura más bien limitativa a la facultad probatoria del juez, cimentada sobre la base de la aportación por defecto, dejando entregada a las partes en forma primaria e incluso excluyente la iniciativa de prueba, a fin de que el Tribunal solo en defecto de la prueba rendida por ellas pueda ejercer sus potestades probatorias. En otras palabras, las potestades probatorias del Tribunal no pueden ser sustitutivas a la actividad de las partes, sino que tan solo complementarias; por mucho que el juez deba proteger ciertos intereses en el conflicto familiar, ello no lo autoriza para pasar por encima de la propia actividad probatoria de las partes. Ello no obsta claro está que el juez en la audiencia preparatoria pueda ampliar la prueba ofrecida por las partes.

Ortells, no obstante mostrarse contrario a la iniciativa probatoria del Tribunal, agrega una variante que autorizaría la utilización de dicha potestad. En efecto, el autor expresa que "si las partes han sido diligentes en la proposición y práctica de los medios de prueba y su iniciativa se ha visto frustrada por causas ajenas a su voluntad, el juez ha de hacer lo necesario para la práctica -in extremis, como diligencias finales- de los medios de prueba fallidos" ${ }^{47}$ Se trata que el Tribunal pueda decretar una diligencia probatoria frente a una prueba aportada y ofrecida por la parte -un informe social, psicológico, declaración de testigo, etc.- que se ha visto frustrada por causas no imputables.

tal práctica no se condice con la naturaleza del procedimiento que exige celeridad, concentración e inmediación, y la práctica probatoria fuera de la audiencia de juicio claramente denota su incompatibilidad con la naturaleza del proceso. A lo anterior se debe agregar que el Proyecto de Ley original contemplaba en el Art. 31 la posibilidad de que el juez pueda, en cualquier estado de procedimiento, decretar diligencias probatorias, potestad que fue suprimida por el texto actual, limitándola solo a la audiencia preparatoria. Vid. Mensaje del Presidente de la República al Proyecto de Ley que crea los Tribunales de Familia, Boletín No 2118-18, p. 12. Se añade a lo anterior lo sustentado por Cortez quien sostiene dos cuestiones al efecto: primero, que en el procedimiento de los Tribunales de Familia no existe el trámite de citación a oír sentencia, que marca el momento desde el cual el juez de familia puede decretar medidas para mejor resolver; y segundo, que no aparece claramente configurada la oportunidad procesal en la que el juez pueda hacer uso de las medidas para mejor resolver. Vid. "Breves comentarios sobre los principios del procedimiento, la prueba y la cautela en el proyecto de ley que crea los Tribunales de Familia”, op. cit., p. 103.

46 Taruffo, M.: "Investigación judicial y producción de prueba por las partes", en Revista de Derecho Universidad Austral de Chile, Vol. XV, diciembre 2003, p. 211. En el mismo sentido: Silva, J.: "Iniciativa probatoria del Tribunal en el nuevo orden procesal civil", en Hacia una Nueva Justicia Civil, Boletín Jurídico del Ministerio de Justicia, $\mathrm{N}^{\circ}$ 7, año 4, 2005, p. 28, quien habla derechamente de una función subsidiaria del Tribunal en este sentido, expresión que dado el alcance eminentemente político y no técnico he preferido no utilizar.

${ }^{47}$ Ortells, M.: "Me inclino por el juez activo en la Dirección del Proceso", en Hacia una Nueva Justicia Civil, Boletín Jurídico del Ministerio de Justicia, $\mathrm{N}^{\circ}$ 7, año 4, 2005, p. 50. 
Esta posibilidad, de un alto grado de conveniencia, no ha de ser posible bajo la forma de la actual Ley, ya que el infortunio probatorio solo será posible determinarlo en la audiencia de juicio, donde el juez no puede proponer prueba. Así las cosas, reconociendo la factibilidad de tal posibilidad -que respeta por completo la garantía f) señalada- creo indispensable una modificación legislativa, a fin de que el juez pueda suspender la audiencia de juicio cuando la prueba ofrecida por las partes e incluso por el juez no se encuentre disponible para su rendición por causas ajenas y se trate de un medio probatorio indispensable o esencial. De igual forma, esta potestad, a mi juicio, solo puede ser ejercida a petición parte o de oficio por el juez, en la misma audiencia de juicio, previo debate entre las partes, asegurando de esa forma la contradicción, y limitada tan solo a las fuentes probatorias frustradas. Ni el juez ni las partes pueden ofrecer nueva prueba, sino tan solo discutir sobre la producción de la ya ofrecida.

No obstante lo ya dicho, la Ley no contempla una limitación al juez para aportar prueba sobre la base de las fuentes probatorias existentes en el proceso. Es más, su actual configuración lo autoriza para desligarse por completo de las pruebas ofrecidas por las partes y rendir su propia prueba. Esta cuestión resulta de suma lógica en el entramado normativo existente desde que el juez no puede basarse en el mérito de la prueba entregada por las partes para decidir la utilización de sus potestades. Así, el cumplimiento de esta garantía que permite al juez aportar prueba conforme a las fuentes probatorias que ya existen en el proceso me parece que es un coto insalvable, que solo resultaría aplicable cuando el juez tenga a su disposición todo el haz probatorio, el que solo será efectivo una vez finalizada la audiencia de juicio. Por lo mismo, esta garantía no operaría sino bajo una reforma legislativa como la propuesta en el párrafo anterior.

\subsection{Potestad probatoria y la posibilidad de rendir contraprueba}

Una forma de hacer efectivo el derecho a defensa de las partes frente a la actividad probatoria del Tribunal es dándole la posibilidad de rendir contraprueba (garantías c) y g)). Esta no es más que la posibilidad de la parte de ofrecer medios de prueba destinados a destruir las ofrecidas por el Tribunal. No se trata por cierto de una equivalencia probatoria en términos de que si el juez ofrece un informe sicológico la parte tiene la posibilidad solo de ofrecer otro informe en el mismo sentido o si el juez ofrece un informe social la parte ofrezca otro, etc. No hay una exigencia de identidad entre la prueba ofrecida por el juez y la contraprueba de la parte. De igual modo, no se infringe la garantía si la parte decide no rendir contraprueba y renuncia a tal posibilidad, ya que la garantía se agota con la simple posibilidad de aportar prueba.

Sin embargo, un atento examen de esta garantía supone que las partes y el juez conocen el contenido o mérito de los elementos probatorios rendidos en el proceso, de ahí que tengan la opción de contraprobar, es decir, mostrar la verdad o falsedad de las afirmaciones que se intentan demostrar con la prueba del juez, lo que solo estarán en condición de hacer si conocen el resultado de la prueba. Ahora bien, si al menos formalmente las partes pueden en la audiencia preparatoria ofrecer prueba para contrarrestar la ofrecida por el Tribunal, tal posibilidad solo queda limitada a la simple ampliación de 
las pruebas ofrecidas inicialmente, sin la posibilidad -cierta- de rendir contraprueba. $\mathrm{Ni}$ las partes ni el juez tienen la opción de ofrecer medios de prueba después de finalizada la audiencia de juicio.

En este sentido, a fin de asegurar esta posibilidad de ampliar las pruebas ofrecidas por las partes, a mi juicio, el juez debe tener especial cuidado con la interpretación del Art. 31 de la Ley, en especial en la calificación de las pruebas sobreabundantes. En efecto, no podrían calificarse de sobreabundante, y por ende ser excluidas, aquellas probanzas destinadas a contrarrestar la prueba ofrecida por el Tribunal, las que debieren ser admitidas en juicio como garantía de la actividad probatoria del Tribunal. Esta es la única interpretación que respeta la garantía del debido proceso del justiciable.

Esta garantía además debe estar lo suficientemente respaldada con la exigencia de la fundamentación probatoria de la sentencia. ${ }^{48}$ Sería irrisoria la potestad de la parte de rendir contraprueba o de ampliar sus pruebas ofrecidas, si el juez en la sentencia no le otorga ningún valor probatorio a dicha prueba y prefiere, sin más, la ofrecida por él. En un Estado de Derecho la función jurisdiccional se caracteriza por la exigencia de racionalidad de las sentencias judiciales como forma de descartar la arbitrariedad, de manera que el juez debe hacerse cargo fundadamente de toda la prueba rendida y explicar las razones del porqué prefiere un medio de probatorio por sobre otro. Solo así podemos verificar la efectividad de la garantía procesal en análisis.

\subsection{Potestad probatoria y el contradictorio, la publicidad y la inmediación}

Vistos los límites de la potestad probatoria del Tribunal y una posible interpretación de lege lata de los textos normativos, corresponde referirse a la misión que debe jugar el contradictorio en la operatividad de dichas garantías.

En este sentido, si hay que agradecer algo a la Ley es precisamente que la introducción de la prueba del juez se realiza bajo el estricto cumplimiento del contradictorio, acompañado de la inmediación y publicidad. Como lo sostiene Picó i Junoy, "es necesario que en el desarrollo de la prueba practicada a instancia del órgano jurisdiccional se respete escrupulosamente el principio de contradicción, esto es, el derecho de defensa de las partes que poseen en la ejecución de cualquier medio probatorio". ${ }^{49}$ Le está vedado al órgano estatal introducir prueba sin la presencia de las partes, en su oscuro despacho y sin previo debate. ${ }^{50}$ Las partes tienen la genuina posibilidad de acotar el material probatorio sobre la base de las garantías señaladas, es decir, discutir para limitarlas a

${ }^{48}$ Sobre el tema puede verse: Accatino, D.: "Fundamentación de las sentencias: ¿un rasgo distintivo de la judicatura moderna", en Revista de Derecho Universidad Austral de Chile, Vol. XV, diciembre 2003, p. 9-35.

${ }^{49}$ Pico i Junoy, J.: "La iniciativa probatoria del juzgador penal y la imparcialidad judicial”, op. cit., p. 384. Del mismo autor: "Los principios del Nuevo Proceso Civil Español", en XVII Jornadas Iberoamericanas, XI Jornadas Uruguayas de Derecho Procesal, en Homenaje a la Escuela Procesalista Uruguaya, 16 al 18 de octubre de 2002, Fundación de Cultura Universitaria, Montevideo, p. 192.

${ }^{50}$ Vid. Klett, S.: "La Prueba en el Proceso Civil", en Seminarios de Derecho Procesal, Universidad Diego Portales, Serie de Publicaciones especiales No 17, p. 44. 
los hechos alegados por las partes, controvertir la pertinencia o relevancia de la prueba que se desea introducir, ampliar sus pruebas inicialmente propuestas, etc.

Con todo, la única forma que tienen las partes de controlar ab initio la procedencia y la admisibilidad de las pruebas, tanto del juez como de la contraparte, es mediante una conjugación de los principios de bilateralidad y contradicción, pudiendo objetar medios de prueba inadmisibles, manifiestamente inconducentes o impertinentes, ${ }^{51}$ entendiéndose por tales aquellos que busquen acreditar proposiciones no introducidas por las partes o sobre fuentes probatorias que no constan en el proceso. "La idea es que el hecho de decretarse una prueba se ponga en conocimiento de la parte contraria y al momento de verificarse el medio probatorio se dé oportunidades a ambas a contradecir y contraprobar". 52

En cuanto a la publicidad de la prueba esto implica "la posibilidad de que las partes y terceras personas puedan reconstruir las motivaciones que determinaron la decisión, en otras palabras, que el examen y las conclusiones del juez sobre la prueba deban ser conocidas por las partes y estar al alcance de cualquier persona que se interese en ello". 53 La publicidad en la aportación de las pruebas permite ejercer un control procesal y extraprocesal por las partes y por terceros respecto del material probatorio introducido por el juez. El diseño procedimental sobre la base de audiencias públicas y la inmediación favorece el cumplimiento de las garantías procesales señaladas. Con esto se asegura que será solo el juez quien aportará prueba al proceso y no un funcionario del Tribunal, es decir, solo el decidor final contempla la plenitud de potestades para aportar material probatorio. Estas exigencias se cumplen de sobra bajo la actual normativa de familia, ya que el juez solo aportará prueba bajo la inmediación, publicidad y contradicción, lo que constituye un claro avance en los modelos procesales civiles chilenos.

Con todo, esto reafirma aun más que nuestra doctrina procesal debe preocuparse del estudio de los límites de la prueba oficiosa, ya que estas formas procesales parecen estar lo suficientemente asumidas en el nuevo marco procesal como presupuestos de actuación válida del Tribunal.

\section{Conclusiones}

1. La doctrina procesal ha terciado sobre la problemática de atribuir poderes al juez civil estructurando dos grandes tesis: la primera que vincula la potestad probatoria material a la pérdida de imparcialidad del juzgador, y la otra, que la visualiza como una mera cuestión técnica necesaria para la resolución legitimada del conflicto.

${ }^{51}$ Ibid., p. 43.

52 Jara, E.: "Comentario a la conferencia de la profesora Dra. Selva Klett (La Prueba en el proceso Civil)", en Seminarios de Derecho Procesal, Universidad Diego Portales, Serie de Publicaciones especiales No 17 , p. 52.

53 Gómez, C.: Derecho Procesal Civil, Colección Textos Jurídicos Universitarios Oxford, México, 1998, p. 103 . 
2. En materia de familia pueden visualizarse con suma nitidez potestades oficiosas ligadas a los tiempos procesales, y otras ligadas al contenido material del proceso. Estas últimas pueden ser directas o indirectas.

3. Los fundamentos de las potestades materiales del juez de familia tienen una doble vertiente claramente definida; unas tantas propias del ámbito donde opera (configuración previa del derecho sustancial y traslación de la preocupación estatal hacia la esfera del conflicto familiar) y otras propias de la función jurisdiccional y del rol que debe asumir el juez en el conflicto (búsqueda de la verdad como legitimadora de la decisión).

4. Una concepción de la prueba fundamentada en la convicción íntima del juzgador sobre la base de las pruebas rendidas no resulta adecuada para sustentar una tesis contraria al aporte probatorio del Tribunal, adoleciendo además de graves problemas en torno a la fundamentación de la sentencia.

5. Siendo claro que prácticamente todas las legislaciones vertebran un conjunto no despreciable de potestades materiales de los jueces civiles, especialmente en materia probatoria, la discusión teórica debería trasladarse a los presupuestos de operatividad de tales poderes a fin encontrar sus límites necesarios para el respeto al debido proceso.

6. En este sentido, tales presupuestos deberían ser los siguientes: a) Posibilidad de las partes de controvertir la pertinencia o relevancia de la prueba que se intenta introducir; b) Participar en su realización; c) Producir contraprueba; d) Discutir acerca de la eficacia de la prueba de oficio antes de la decisión; e) que la potestad probatoria se limite a los hechos discutidos en el pleito; f) a las fuentes probatorias que ya constan en la causa, y g) se permita ejercer el derecho de defensa a los litigantes, ampliando sus pruebas inicialmente propuestas.

7. Estas garantías deben desarrollarse bajo un necesario contradictorio, que se erige no solo en una garantía procesal de carácter general, sino que además y en el campo específico de la utilización de poderes materiales del juez, constituye un presupuesto de actuación del órgano jurisdiccional, previo y necesario para la verificación de las restantes garantías.

8. En materia de familia la potestad material del juez no está limitada a los hechos aportados por las partes sino que a la naturaleza del conflicto que se trate. Esta fórmula, de difusos límites, ha de obligar al operador a efectuar una interpretación conforme al debido proceso, a fin de limitar la potestad material solo a los hechos alegados por las partes.

9. Solo resulta lícito al juez introducir prueba al proceso cuando las partes no hayan ofrecido la suya frente a determinados hechos, y no cuando ésta resulta insuficiente. Además le está permitido producir prueba cuando la ofrecida no ha podido rendirse por causas no imputables a las partes. Esta última posibilidad no resulta operativa bajo la actual normativa, por lo que se hace necesaria una reforma legislativa en tal sentido.

10. El actual diseño de la Ley impide a las partes rendir contraprueba, pudiendo tan solo ampliar las inicialmente ofrecidas. Para ello se hace indispensable que el juez 
no califique de sobreabundante aquel material probatorio introducido por las partes para desvirtuar la prueba ofrecida por el Tribunal.

11. La actividad oficiosa material del Tribunal debe desarrollarse bajo el estricto cumplimiento de la forma del contradictorio, la publicidad y la inmediación. Solo así es posible la operatividad de las garantías procesales de control de la actividad probatoria.

\section{BIBLIOGRAFÍA}

Accatino Scagliotti, Daniela: "Fundamentación de las sentencias: ¿un rasgo distintivo de la judicatura moderna", en Revista de Derecho Universidad Austral de Chile, Vol. XV, diciembre, 2003.

- $\quad$ "La fundamentación de la declaración de los hechos probados en el nuevo proceso penal. Un diagnóstico", en Revista de Derecho Universidad Austral de Chile, Vol. XIX, N²2, diciembre, 2006.

Barros Bourie, Enrique: "La ley civil ante las rupturas matrimoniales", en Estudios Públicos $\mathrm{N}^{\circ} 85,2002$.

Berizonce, Roberto Omar: "Tribunali e proccesi di famiglia", en Rivista Trimestrale di Diritto e Procedura Civile, $\mathrm{N}^{\circ}$ 2, Vol. LVII, 2003.

Bordalí Salamanca, Andrés: "El debido proceso civil", en La Constitucionalización del Derecho Chileno, Ferrada, J.C. (Coordinador), Universidad Austral de Chile, Editorial Jurídica de Chile, Santiago, 2003.

Bordalí Salamanca, Andrés: "Los Poderes del Juez Civil", en Pensando en una nueva Justicia Civil, Editorial Jurídica de Chile (en prensa).

Botto Oakley, Hugo: Inconstitucionalidad de las Medidas para Mejor Resolver, Editorial Fallos del Mes, 2001, Santiago de Chile.

Cabañas García, Juan Carlos: La valoración de las pruebas y su control en el proceso civil, Editorial Trivium, Madrid, 1992.

Cappelletti, Mauro: Guistizia e Società, Edizione di Comunità, Milán, 1972.

Cipriani, Franco: Ideologie e modelli del processo civile, Edizioni Scientifiche Italiane, Nápoles, 1997.

- "El proceso civil entre viejas ideologías y nuevos eslóganes", en Proceso Civil e Ideología: un prefacio, una sentencia, dos cartas y quince ensayos, Editorial Tirant Lo Blanch, Valencia, 2006.

Comoglio, Luigi Paolo: "Garanzie Minime del 'Giusto Processo' Civile Negli Ordenamenti Latinoamericani”, en Rivista di Diritto Dell Integrazione e Unificacione del Diritto in Europa e in America Latina, $\mathrm{N}^{\circ}$ 17, 2004.

Cortez, Matcovich, Gonzalo: "Breves comentarios sobre los principios del procedimiento, la prueba y la cautela en el proyecto de ley que crea los Tribunales de Familia", en Revista de Derecho de la Universidad de Concepción, N²09, año 2001.

Corral Talciani, Hernán: "Claves para entender el derecho de familia contemporáneo", en Revista Chilena de Derecho, Vol. 29, No 1, 2002.

Dellepiane, Antonio: Nueva Teoría de la Prueba, Editorial Temis, Bogotá, 2003.

Ferrer Beltrán, Jordi: Prueba y verdad en el Derecho, Editorial Marcial Pons, Madrid, 2002.

Gómez Lara, Cipriano: Derecho Procesal Civil, Colección Textos Jurídicos Universitarios Oxford, México, 1998. 
González Pérez, Jesús: El Derecho a la Tutela Jurisdiccional, Editorial Civitas, $3^{\text {a }}$ edición, Madrid, 2001.

Jara Castro, Eduardo: "Los procedimientos de la Ley 19.968, a la luz de los principios", en Derecho de Familia e Infancia, Seminario Internacional, Academia Judicial de Chile, 2005.

- "Comentario a la conferencia de la profesora Dra. Selva Klett (La Prueba en el proceso Civil)", en Seminarios de Derecho Procesal, Universidad Diego Portales, Serie de Publicaciones especiales $\mathrm{N}^{\circ} 17$.

Jiménez Asencio, RAFAel: Imparcialidad Judicial y Derecho al Juez Imparcial, Editorial Aranzadi, Navarra, 2002.

Klett Fernández, Selva: "La Prueba en el Proceso Civil", en Seminarios de Derecho Procesal, Universidad Diego Portales, Serie de Publicaciones especiales $\mathrm{N}^{\circ} 17$.

Marín González, Juan Carlos: Las Medidas Cautelares en el Proceso Civil Chileno. Doctrina, jurisprudencia y derecho comparado, Editorial Jurídica de Chile, Santiago, 2004.

Matheus López, Carlos: "Reflexiones en torno a la función y objeto de la prueba", en Revista de Derecho Universidad Austral de Chile, Vol. XIV, 2003, p. 176.

Meneses Pacheco, Claudio: Iniciativa Probatoria del Juez Civil, Editorial Conosur Ltda., 2001, Santiago de Chile.

Mensaje del Presidente de la República al Proyecto de Ley que crea los Tribunales de Familia, Boletín No 2118-18.

Monteleone, Girólamo: "Principios e ideologías del proceso civil. Impresiones de un 'revisionista", en Proceso Civil e Ideología: un prefacio, una sentencia, dos cartas y quince ensayos, Editorial Tirant Lo Blanch, Valencia, 2006.

Montero Aroca, Juan: "El proceso civil llamado "social" como instrumento de "justicia" autoritaria", en Proceso Civil e Ideología: un prefacio, una sentencia, dos cartas y quince ensayos, Editorial Tirant Lo Blanch, Valencia, 2006.

- "Sobre el mito autoritario de la 'buena fe procesal”, en Proceso Civil e Ideología: un prefacio, una sentencia, dos cartas y quince ensayos, Editorial Tirant Lo Blanch, Valencia, 2006.

- Los principios políticos de la nueva ley de Enjuiciamiento Civil. Los poderes del juez y la oralidad, Editorial Tirant Lo Blanch, Valencia, 2001.

Ortells Ramos, Manuel: "Me inclino por el juez activo en la Dirección del Proceso", en Boletín Jurídico del Ministerio de Justicia, $\mathrm{N}^{\circ}$ 7, año 4, 2005.

Ortells Ramos, Manuel: Las Medidas Cautelares, $1^{\text {a }}$ edición, Editorial La Ley, Madrid, 2000.

Palomo Vélez, Diego: Proceso Civil Oral: ¿Qué modelo de juez requiere?, en Revista de Derecho Universidad Austral de Chile, Vol. XVIII, Nº 1, julio, 2005.

- $\quad$ "Sobre el papel del juez civil en materia de prueba, especialmente de las medidas para mejor resolver. A propósito de la paradoja que evidencia nuestro sistema procesal tras la Reforma procesal penal", en Revista Gaceta Jurídica, junio 2005.

Picó I JunOY, JoAN: "El derecho procesal entre el garantismo y la eficacia: Un debate mal planteado”, en Proceso Civil e Ideología, Montero Aroca (coord.), Editorial Tirant Lo Blanch, Valencia, 2006.

- "La iniciativa probatoria del juzgador penal y la imparcialidad judicial", en XVII Jornadas Iberoamericanas, XI Jornadas Uruguayas de Derecho Procesal, en Homenaje a la Escuela Procesalista Uruguaya, 16 al 18 de octubre de 2002, Fundación de Cultura Universitaria, Montevideo.

- "Los principios del Nuevo Proceso Civil Español”, en XVII Jornadas Iberoamericanas, XI Jornadas Uruguayas de Derecho Procesal, en Homenaje a la Escuela Procesalista Uruguaya, 16 al 18 de octubre de 2002, Fundación de Cultura Universitaria, Montevideo.

Silva Prado, José: "Iniciativa probatoria del Tribunal en el nuevo orden procesal civil", en Boletín Jurídico del Ministerio de Justicia, $\mathrm{N}^{\circ}$ 7, año 4, 2005. 
Tapia Rodríguez, Mauricio: Código Civil 1855-2005. Evolución y Perspectivas, Editorial Jurídica de Chile, 2005, Santiago.

Taruffo, Michele: "Algunos comentarios sobre la valoración de la prueba”, en Discusiones (Publicaciones periódicas), $\mathrm{N}^{\mathrm{o}}$ 3, 2003.

- "Idee per una teoria della decisione giusta”, en Sui Confini, Scritti sulla giustizia civile, Bolonia, 2002.

- "Investigación judicial y producción de prueba por las partes", en Revista de Derecho Universidad Austral de Chile, Vol. XV, diciembre 2003.

Verde, Giovanni: "Las ideologías del proceso en un reciente ensayo", en Proceso Civil e Ideología: un prefacio, una sentencia, dos cartas y quince ensayos, Editorial Tirant Lo Blanch, Valencia, 2006.

- "Le ideologie del processo in un recente saggio", en Rivista di Diritto Processuale, año LVII (seconda serie), $\mathrm{N}^{\circ}$ 3, 2002. 
